IZA DP No. 7511

After the Farm Crisis:

Religiosity in the Rural United States

Wafa Hakim Orman

July 2013 


\title{
After the Farm Crisis: Religiosity in the Rural United States
}

\author{
Wafa Hakim Orman \\ University of Alabama in Huntsville \\ and IZA
}

Discussion Paper No. 7511 July 2013

IZA
P.O. Box 7240
53072 Bonn
Germany

Phone: +49-228-3894-0

Fax: +49-228-3894-180

E-mail: iza@iza.org

Any opinions expressed here are those of the author(s) and not those of IZA. Research published in this series may include views on policy, but the institute itself takes no institutional policy positions. The IZA research network is committed to the IZA Guiding Principles of Research Integrity.

The Institute for the Study of Labor (IZA) in Bonn is a local and virtual international research center and a place of communication between science, politics and business. IZA is an independent nonprofit organization supported by Deutsche Post Foundation. The center is associated with the University of Bonn and offers a stimulating research environment through its international network, workshops and conferences, data service, project support, research visits and doctoral program. IZA engages in (i) original and internationally competitive research in all fields of labor economics, (ii) development of policy concepts, and (iii) dissemination of research results and concepts to the interested public.

IZA Discussion Papers often represent preliminary work and are circulated to encourage discussion. Citation of such a paper should account for its provisional character. A revised version may be available directly from the author. 


\section{ABSTRACT}

\section{After the Farm Crisis: Religiosity in the Rural United States}

The farm crisis in the United States in the 1980s had profound effects on rural, agricultural regions of the country, but almost no impact on urban and suburban areas. I use a difference-in-difference methodology and find that religiosity as measured by religious attendance increased significantly in areas impacted by the crisis for those who worked in agriculture. Chen (2010) describes increased religiosity in Indonesia following the 1998 financial crisis, and this paper demonstrates a similar response to severe financial distress in the United States. I also find evidence that this increase is not due to a lower opportunity cost of time, as those who are currently employed have higher levels of attendance than those who are not. I hypothesize that the increased religiosity results from religious institutions' ability to provide public goods, both financial and emotional, in the form of community support.

JEL Classification: J22, Q12, Z12

Keywords: farm crisis, financial distress, religious attendance, religiosity

Corresponding author:

Wafa Hakim Orman

College of Business Administration

University of Alabama in Huntsville

Huntsville, AL 35899

USA

E-mail:wafa.orman@uah.edu 


\section{Introduction}

The rise in farm land prices due to the commodity price boom in the late 1970s, followed by the subsequent price crash in the 1980s, profoundly reshaped the economic and social landscape of the rural United States. This study measures the effects of the farm crisis on religious behavior and adherence in regions affected by the farm crisis.

Iannaccone (1992) and Berman (2009) hypothesize that strict religions and sects can provide more public goods and benefits to their members by successfully excluding free-riders. A corollary of this theory suggests that during times of economic or social distress, people will be drawn to religious organizations that provide mutual aid and benefits, and that these will tend to be more strict and demanding. For example, Chen (2010) demonstrates that in Indonesia after the 1998 financial crisis which led to massive, widespread inflation, the ability to grow food gave households with greater wetland holdings a better cushion against consumption shocks. He finds that members of households which suffered greater real consumption shocks were more likely to enroll in Quran study classes, locally known as "pengajian," and send their children to Islamic schools, despite higher tuition and worse labor market returns from Islamic schools. Enrollment in Quran study classes in turn improved later outcomes for the affected households they did not require as much assistance or alms in subsequent months.

The United States has suffered its fair share of financial crises with their roots in highly leveraged real estate bubbles - in the $1920 \mathrm{~s}, 1980 \mathrm{~s}$, and more recently post-2007. The $1980 \mathrm{~s}$ farm crisis presents a particularly interesting case, since the effects on rural areas were 
devastating, while urban and suburban areas were largely unaffected. ${ }^{1}$ If increased religiosity in response to financial distress occurred in Indonesia, might it also have occurred in the US? If so, what are the implications for policymakers, particularly in light of the recent financial crisis that began in $2007 ?$

\section{The Farm Crisis: Background}

In the 1970s, rising global commodity prices led to an export boom for American farmers, encouraging them to expand production greatly by investing in both land and equipment. A major portion of this expansion was funded by debt, particularly from local farm credit organizations. Many of the borrowers were younger and more highly educated than the average farmer, as they tended to be more likely to ramp up investment and expand to take advantage of rising global commodity prices. However, as interest rates rose in the early 1980 s, the dollar appreciated and exports fell. At the same time, farmers who had accumulated high levels of debt in prior years found it increasingly difficult to service their debt. Farm and farm bank failures increased, leading to a steep decline in farm real estate prices. The crisis began in the Corn Belt and Northern Plains states, but then spread outward and westward by the mid-1980s as shocks to the farm credit system were propagated by increasing numbers of bankruptcies, impacting entire communities across the rural United States. (Calomiris et. al., 1986; Harl, 1990; Murdock and Leistritz, 1988) Figures 1, 2 and 3 use data from the Agricultural Census, conducted every 5 years, to illustrate the pattern of the initial increase in real farm prices per acre (adjusted to 2007

\footnotetext{
${ }^{1}$ Interestingly, this was not even the first such credit-driven farm land crisis in the United States in the $20^{\text {th }}$ century Rajan and Ramachandran (2012) document the 1920s farm crisis, which played out in a similar way.
} 
dollars) during the 1970s, followed by the crash in the 1980s. In the upper Midwest, for example, farm prices increased by over $60 \%$ in the 1970 s, but then crashed by almost $70 \%$ in the worstaffected areas between 1978 and 1982, and then fell again by almost 70\% between 1982 and 1987.

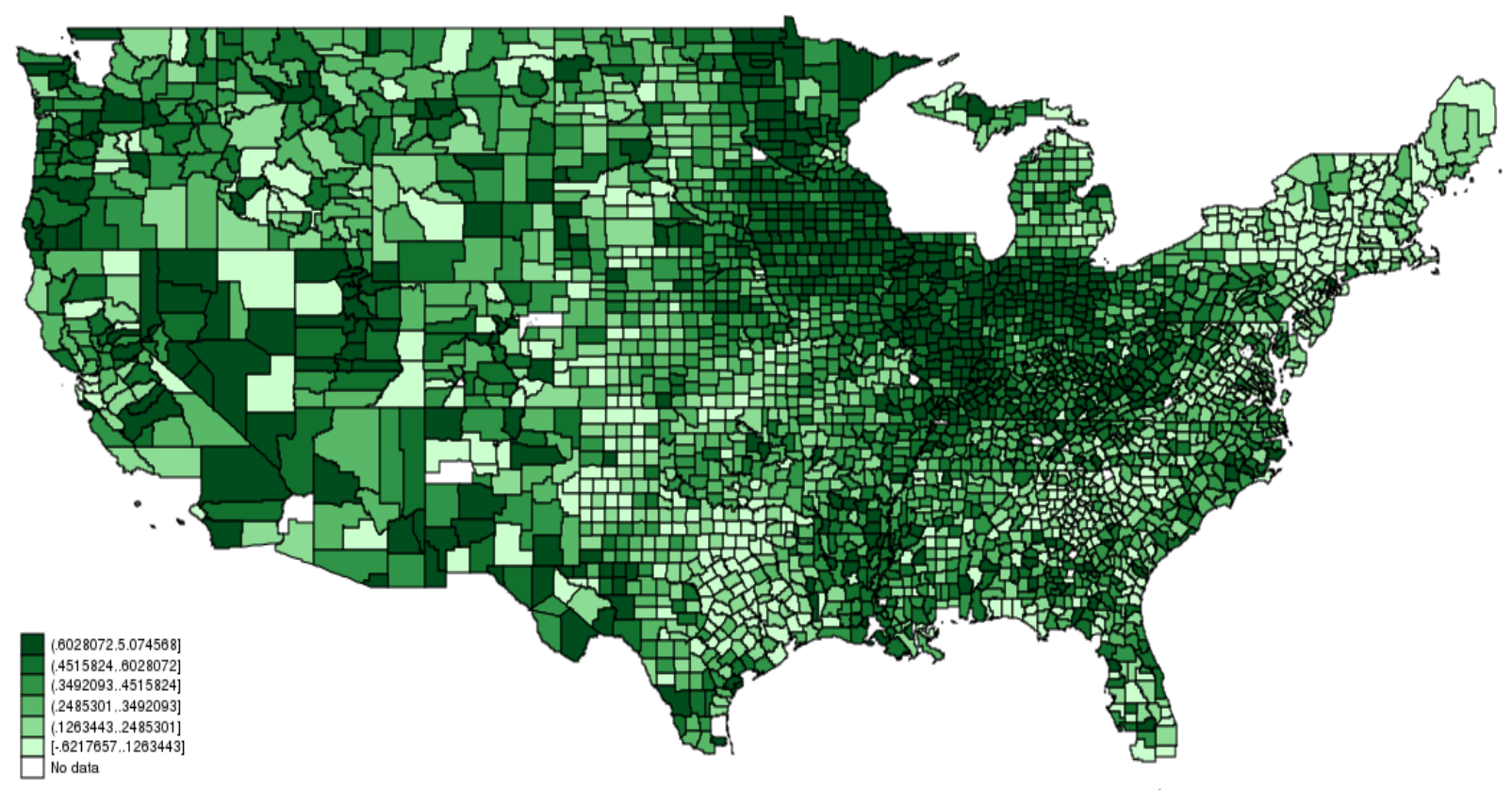

Figure 1: Percentage increase in per-acre farm land prices, 1974-1978 


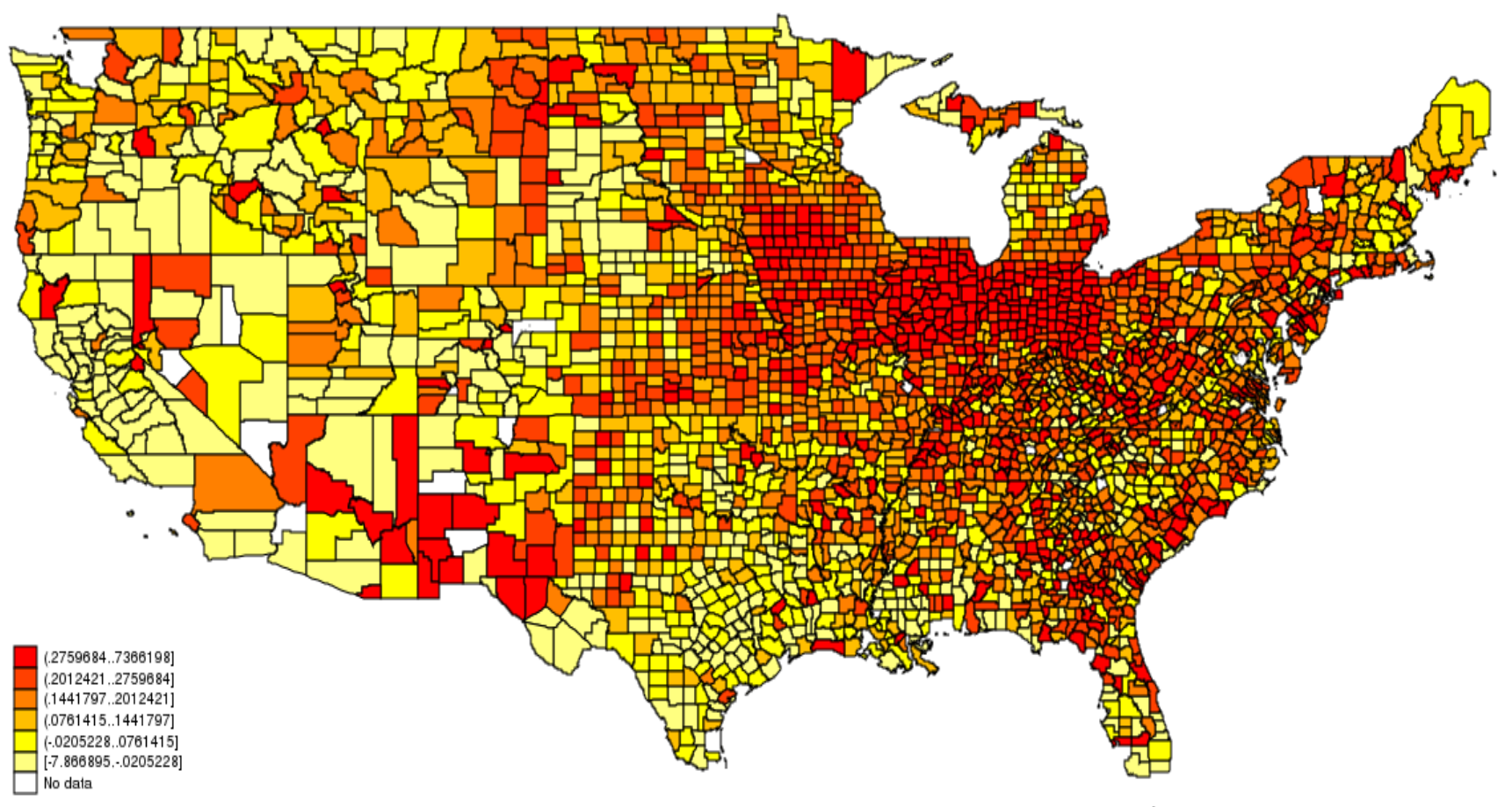

Figure 2: Percentage decline in per-acre farm land prices, 1978-1982

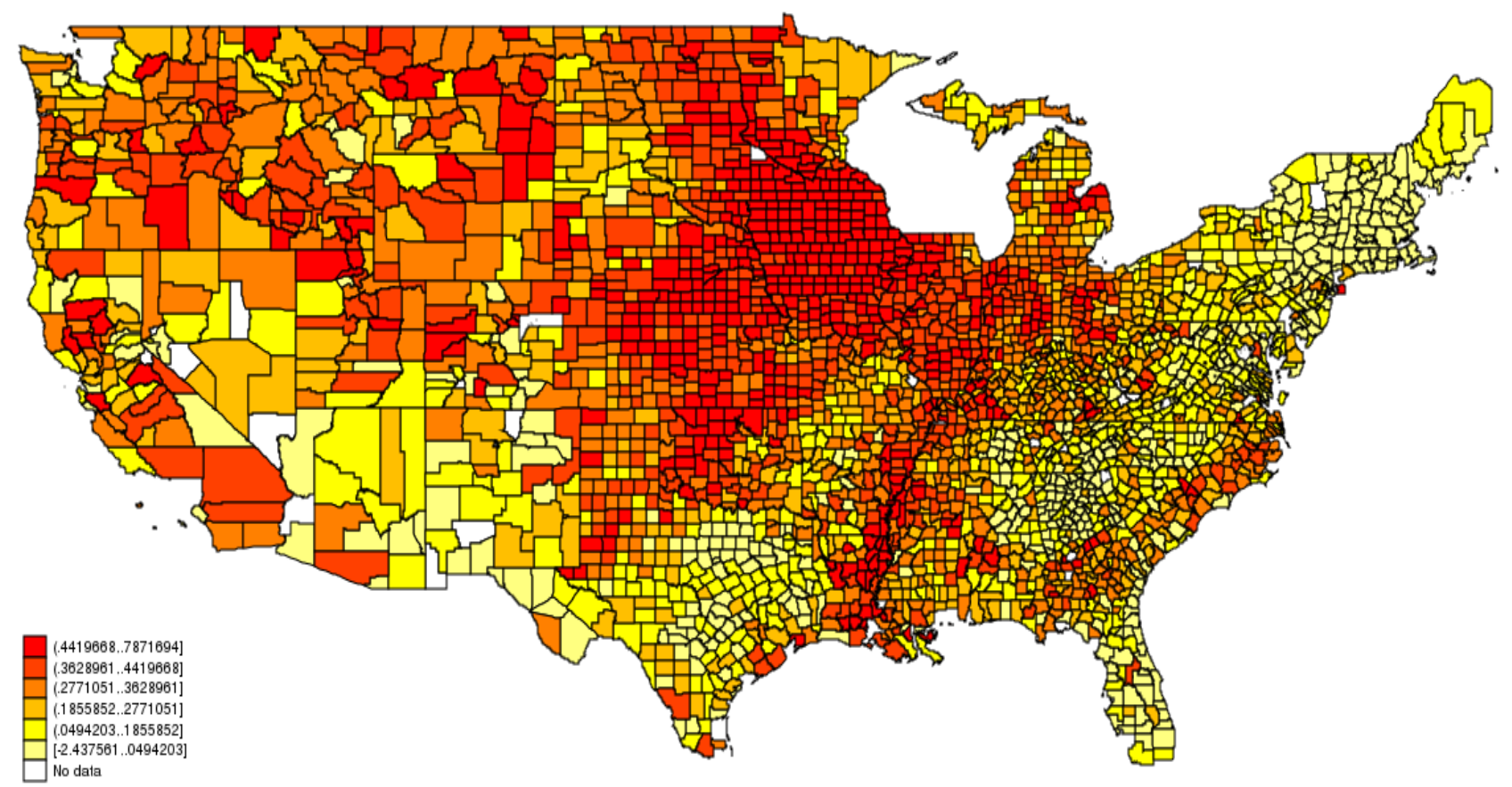

Figure 3: Percentage decline in per-acre farm land prices, 1982-1987 
A large body of research documents the effect of the farm crisis on the stress levels and mental health of farm families, and the relationship this has with religiosity. (Davis-Brown and Salamon, 1987; Geller et. al., 1988; Hoyt et. al., 1995, Lorenz et. al., 2000; Meyer and Lobao, 2003; Ortega et. al., 1994; Thompson and McCubbin, 1987) In particular, Meyer and Lobao (2003) describe improved mental health outcomes for those who attend religious services regularly versus those who don't, in a rural Ohio community impacted by the farm crisis.

Gruber and Hungerman (2008) use General Social Survey data to analyze the effect of changes in blue laws on religious attendance in the United States. They find that religious attendance declined as states repealed their blue laws, since secular goods and leisure activities competed for people's time on Sundays. In a similar vein, if those affected by the farm crisis suffered a lowered opportunity cost of time, we might see religious attendance increase. Therefore, there are two mechanisms that could potentially drive increased religious attendance in the aftermath of a financial crisis: a need for the public goods these communities provide (which may even include companionship and emotional support, as the church becomes a focal place for local residents to gather), and the reduced opportunity cost of time.

\section{Model and Data}

In this paper, I use General Social Survey data from 1974 to 2000 to obtain a broader view of national trends in religiosity through the 1970s, 1980s, and 1990s, and by identifying areas affected by the farm crisis, to measure the differences between those areas and the rest of the country. For the 1970s and the 1980s beginning in 1974, the GSS identifies a respondent's 
"Primary Sampling Unit," which corresponds to a metropolitan statistical area for those who live in one, and a county or township for those who live in a rural area. The respondent's Primary Sampling Unit, or PSU, is therefore how I define a respondent's area of residence.

I also measure differences by occupation, and compare those working in agriculture with those working in state, local, or federal government, as a placebo instrument. I find that people who worked in agriculture in areas which suffered a decline in real farm prices attend religious services more frequently than those who did not. I then test whether this impact was a result of cultural shifts in these affected areas as opposed to social insurance by examining those who live in affected areas but work in government.

An individual's religious attendance is determined as follows:

$$
\begin{gathered}
R_{i j t}=\beta_{0}+\alpha_{1} \text { Decline }_{j t}+\alpha_{2} \text { Farm Intensity }_{j t}+\alpha_{3} \text { Ag }_{i j t}+\alpha_{4} \text { Decline }_{j t} * \text { Ag }_{i j t} \\
+\boldsymbol{\beta} \boldsymbol{X}_{i j t}+\gamma \boldsymbol{e}_{j t}+\boldsymbol{\delta} u_{j}+\tau v_{\mathrm{t}}+\varepsilon_{i j t}
\end{gathered}
$$

Where $R_{i j t}$ is an ordered variable representing religious attendance, ranging from "never" to "more than once a week," Decline $e_{j t}$ is a dummy variable indicating whether real farm prices per acre fell in the respondent's PSU between two agricultural censuses. For example, if the real price in PSU $j$ is lower in the 1982 census than in the 1978 census, Decline $e_{t}$ takes on a value of 1 for PSU $j$ for the years 1978 through $1981 .^{2} A g_{i j t}$ is a dummy indicating whether the respondent works in an agriculture-related industry, $\boldsymbol{X}_{i j t}$ is a vector of individual-specific characteristics, $\boldsymbol{e}_{j t}$ is a vector of PSU-specific characteristics including per capita income and changes in per capita

\footnotetext{
${ }^{2}$ The fact that the Agricultural Census is conducted every 5 years while the GSS is an annual survey makes the use of actual land prices less meaningful, as those are bound to have changed in the time between two Agricultural Censuses.
} 
income, the $u_{j}$ are PSU fixed effects and the $v_{t}$ are year fixed effects. This therefore constitutes a difference-in-difference model, where the coefficient on Decline $_{j t}{ }^{*} A g_{i j t}, \alpha_{4}$, measures the impact of a decline in real farm prices for those working in agriculture as an "average treatment effect" (ATE).

Table 2 contains descriptive statistics for all variables used in the model. All individuallevel data is from the GSS. Data on farm land prices is from the Agricultural Census. Data on per capita incomes and county or MSA characteristics was obtained from the Bureau of Economic Analysis, and were totaled or averaged for a PSU, as appropriate, when they spanned more than one.

Table 2: Summary Statistics

\begin{tabular}{|c|c|c|c|c|c|}
\hline Variable & Obs. & Mean & $\begin{array}{l}\text { Std. } \\
\text { Dev. }\end{array}$ & Min & Max \\
\hline Attendance & 38861 & 3.895 & 2.686 & 0 & 8 \\
\hline Strength of religious affiliation & 36280 & 2.280 & 1.536 & 0 & 4 \\
\hline Age & 39182 & 45.16 & 17.55 & 18 & 89 \\
\hline Mother attended weekly & 39320 & 0.108 & 0.310 & 0 & 1 \\
\hline Father attended weekly & 39320 & 0.076 & 0.264 & 0 & 1 \\
\hline Ever switched religions & 39320 & 0.160 & 0.367 & 0 & 1 \\
\hline Female dummy & 39320 & 0.565 & 0.496 & 0 & 1 \\
\hline Number of children & 39178 & 1.972 & 1.825 & 0 & 8 \\
\hline Married & 39320 & 0.558 & 0.497 & 0 & 1 \\
\hline Employed & 39320 & 0.595 & 0.491 & 0 & 1 \\
\hline Ln(Real personal income) & 23695 & 9.493 & 1.072 & 5.81 & 12.21 \\
\hline PSU population in millions & 39320 & 1.879 & 2.731 & 0 & 10.27 \\
\hline Ln(Real PSU income per capita) & 39127 & 10.20 & 0.235 & 9.24 & 10.84 \\
\hline$\% \Delta$ Real PSU income per capita & 39127 & $1.7 \%$ & $3.5 \%$ & $-38.8 \%$ & $28.9 \%$ \\
\hline Decline in real price of farm land & 39320 & 0.389 & 0.487 & 0 & 1 \\
\hline Work in agriculture & 39320 & 0.024 & 0.154 & 0 & 1 \\
\hline Work in government & 39320 & 0.063 & 0.243 & 0 & 1 \\
\hline Farm revenue/Total PSU income & 39127 & 0.078 & 0.13 & 0 & 1.14 \\
\hline $\begin{array}{l}\text { Farm employment/Total PSU } \\
\text { employment }\end{array}$ & 39127 & 0.048 & 0.56 & 0 & 0.40 \\
\hline
\end{tabular}


Table 2, continued: Distributions of categorical variables:

\begin{tabular}{|c|c|}
\hline Religious Denomination & Percent of sample \\
\hline Protestant & $61.87 \%$ \\
\hline Catholic & $24.69 \%$ \\
\hline Jewish & $2.08 \%$ \\
\hline None & $8.75 \%$ \\
\hline Other & $2.08 \%$ \\
\hline Buddhism & $0.07 \%$ \\
\hline Hinduism & $0.03 \%$ \\
\hline Other Eastern & $0.01 \%$ \\
\hline Moslem/Islam & $0.06 \%$ \\
\hline Orthodox Christian & $0.06 \%$ \\
\hline Christian & $0.18 \%$ \\
\hline Native American & $0.02 \%$ \\
\hline Inter/nondenominational & $0.09 \%$ \\
\hline \multicolumn{2}{|l|}{ Highest degree attained } \\
\hline Less than high school & $24.72 \%$ \\
\hline High school & $51.93 \%$ \\
\hline Junior college & $4.54 \%$ \\
\hline Bachelor's & $12.97 \%$ \\
\hline Graduate & $5.84 \%$ \\
\hline \multicolumn{2}{|c|}{ Religious attendance frequency } \\
\hline Never & $15.11 \%$ \\
\hline$>$ Once a year & $8.04 \%$ \\
\hline Once a year & $13.16 \%$ \\
\hline Several times a year & $13.15 \%$ \\
\hline Once a month & $7.34 \%$ \\
\hline $2-3 \mathrm{x}$ a month & $9.04 \%$ \\
\hline Nearly every week & $5.76 \%$ \\
\hline Every week & $20.58 \%$ \\
\hline More than once a week & $7.82 \%$ \\
\hline
\end{tabular}

The average person in the sample attends religious services about once a month, which corresponds to a value of 4 on the attendance scale, though weekly attendance is modal. 0 indicates that the respondent never attends, and a response of 8 indicates attendance several 
times a week. In the GSS, strength of religious affiliation is a categorical variable which takes a value of 1 for "strong," 2 for "not very strong, 3 for "somewhat strong," and 0 for "no religion." I use this variable to create an indicator for strength of affiliation that ranges from 0 (no religion) to 4 (strong affiliation).

\section{Results}

The first model, described in Table 4, is the fixed-effects specification detailed in Equation (1). In order to test the robustness of the model, I also run a placebo model where I examine the effect of a decline in farm land prices for those who work in government, anticipating that government workers were unlikely to have been directly affected by the crisis. Next, I run the same specification with a 5-year lag in the Decline $_{j t}$ variable to measure the effect over a longer period of time. (Table 4) I also test the effect of a decline in farm land prices per acre on each separate category of attendance, from "Never attend" to "Attend more than once a week." (Table 5) Finally, as a robustness check. I use the Churches and Church Membership in the United States data from the Association of Religion Data Archives (ARDA) to measure the effect of declining farm land prices on county-level religious adherence rates, both overall (Table 6) and by denomination (detailed results available by request).

\subsection{Results from Difference-in-Difference specifications}

There are a total of 453 individuals overall in the "treated" group of those who work in agriculture and lived in an area with declining farm prices, and 988 in the placebo group of those 
who work in government and lived in an area with declining farm prices. All regressions have fixed effects for PSUs. Results did not change substantially when state fixed effects were used instead. While the difference-in-difference specification requires the use of OLS to estimate the ATE, robustness checks using ordered logit and ordered probit have qualitatively identical results, which are available by request.

Table 3: Results from Difference-in Difference Model. Dependent variable is religious attendance frequency, OLS with PSU and year fixed effects

\begin{tabular}{|c|c|c|}
\hline & $\begin{array}{c}\text { (1) } \\
\text { Main Model } \\
\end{array}$ & $\begin{array}{c}(2) \\
\text { Placebo Model }\end{array}$ \\
\hline Age & $\begin{array}{c}0.0206^{* * * *} \\
(0.00175)\end{array}$ & $\begin{array}{l}0.0207 * * * \\
(0.00175)\end{array}$ \\
\hline Mother attended weekly & $\begin{array}{c}0.527 * * * \\
(0.0721)\end{array}$ & $\begin{array}{l}0.527 * * * \\
(0.0723)\end{array}$ \\
\hline Father attended weekly & $\begin{array}{c}0.502 * * * \\
(0.0789)\end{array}$ & $\begin{array}{l}0.502 * * * \\
(0.0792)\end{array}$ \\
\hline Ever switched religions & $\begin{array}{l}0.325^{* * *} \\
(0.0518)\end{array}$ & $\begin{array}{l}0.326 * * * \\
(0.0517)\end{array}$ \\
\hline Catholic & $\begin{array}{c}0.381^{* * * *} \\
(0.0533)\end{array}$ & $\begin{array}{l}0.382^{* * * *} \\
(0.0531)\end{array}$ \\
\hline Jewish & $\begin{array}{c}-1.168 * * * \\
(0.106)\end{array}$ & $\begin{array}{c}-1.170^{* * *} \\
(0.106)\end{array}$ \\
\hline No religion & $\begin{array}{c}-2.932 * * * \\
(0.0557)\end{array}$ & $\begin{array}{c}-2.933 * * * \\
(0.0556)\end{array}$ \\
\hline Other religion & $\begin{array}{c}-0.625^{* * *} \\
(0.130)\end{array}$ & $\begin{array}{c}-0.629 * * * \\
(0.130)\end{array}$ \\
\hline Buddhism & $\begin{array}{c}-1.146^{* *} \\
(0.502)\end{array}$ & $\begin{array}{c}-1.135^{* *} \\
(0.499)\end{array}$ \\
\hline Hinduism & $\begin{array}{l}-0.950 \\
(0.774)\end{array}$ & $\begin{array}{l}-0.950 \\
(0.775)\end{array}$ \\
\hline Other Eastern religion & $\begin{array}{c}1.900 * * * \\
(0.276)\end{array}$ & $\begin{array}{c}1.894 * * * \\
(0.285)\end{array}$ \\
\hline Islam & $\begin{array}{c}0.574 \\
(0.884)\end{array}$ & $\begin{array}{c}0.571 \\
(0.884)\end{array}$ \\
\hline Orthodox Christian & $\begin{array}{l}0.0280 \\
(0.314)\end{array}$ & $\begin{array}{l}0.0194 \\
(0.314)\end{array}$ \\
\hline Christian & $0.752 * *$ & $0.743 * *$ \\
\hline
\end{tabular}




\begin{tabular}{|c|c|c|}
\hline & $\begin{array}{c}(1) \\
\text { Main Model } \\
\end{array}$ & $\begin{array}{c}\text { (2) } \\
\text { Placebo Model }\end{array}$ \\
\hline & $(0.329)$ & $(0.330)$ \\
\hline \multirow[t]{2}{*}{ Native American } & -0.822 & -0.829 \\
\hline & $(0.773)$ & $(0.771)$ \\
\hline \multirow[t]{2}{*}{ Inter/Nondenominational } & 0.0841 & 0.0801 \\
\hline & $(0.404)$ & $(0.404)$ \\
\hline \multirow[t]{2}{*}{ Female } & $0.419 * * *$ & $0.414 * * *$ \\
\hline & $(0.0324)$ & $(0.0322)$ \\
\hline \multirow{2}{*}{ Number of children } & $0.0690 * * *$ & $0.0687 * * *$ \\
\hline & $(0.0122)$ & $(0.0121)$ \\
\hline \multirow[t]{2}{*}{ Married } & $0.388 * * *$ & $0.389 * * *$ \\
\hline & $(0.0354)$ & $(0.0354)$ \\
\hline \multirow[t]{2}{*}{ Employed } & $0.108 * *$ & $0.108 * *$ \\
\hline & $(0.0466)$ & $(0.0465)$ \\
\hline \multirow[t]{2}{*}{ Ln(personal income) } & $-0.138 * * *$ & $-0.136^{* * *}$ \\
\hline & $(0.0175)$ & $(0.0175)$ \\
\hline \multirow[t]{2}{*}{ Black } & $0.803 * * *$ & $0.808 * * *$ \\
\hline & $(0.0581)$ & $(0.0582)$ \\
\hline \multirow[t]{2}{*}{ Other race } & $0.477 * * *$ & $0.479 * * *$ \\
\hline & $(0.0799)$ & $(0.0798)$ \\
\hline \multirow[t]{2}{*}{ High school } & $0.543 * * *$ & $0.549 * * *$ \\
\hline & $(0.0509)$ & $(0.0506)$ \\
\hline \multirow[t]{2}{*}{ Junior college } & $0.902 * * *$ & $0.910 * * *$ \\
\hline & $(0.0785)$ & $(0.0780)$ \\
\hline \multirow[t]{2}{*}{ Bachelor's } & $1.223 * * *$ & $1.229 * * *$ \\
\hline & $(0.0666)$ & $(0.0661)$ \\
\hline \multirow[t]{2}{*}{ Graduate degree } & $1.286^{* * *}$ & $1.290 * * *$ \\
\hline & $(0.0821)$ & $(0.0818)$ \\
\hline \multirow{2}{*}{ PSU population in millions } & 0.183 & 0.189 \\
\hline & $(0.150)$ & $(0.150)$ \\
\hline \multirow[t]{2}{*}{ Ln(real per capita PSU income) } & -0.215 & -0.273 \\
\hline & $(0.530)$ & $(0.527)$ \\
\hline \multirow[t]{2}{*}{ Percent change in real per capita PSU income } & 1.058 & 1.003 \\
\hline & $(0.889)$ & $(0.890)$ \\
\hline \multirow{2}{*}{ Farm revenue/Total PSU income } & -0.858 & -0.794 \\
\hline & $(1.180)$ & $(1.177)$ \\
\hline \multirow[t]{2}{*}{ Farm employment/Total PSU employment } & -2.770 & -3.153 \\
\hline & $(2.996)$ & $(2.991)$ \\
\hline \multirow[t]{2}{*}{ Decline in real price of farm land } & 0.0746 & $0.0913 *$ \\
\hline & $(0.0515)$ & $(0.0524)$ \\
\hline \multirow[t]{2}{*}{ Work in agriculture } & -0.233 & \\
\hline & $(0.168)$ & \\
\hline \multirow[t]{2}{*}{ Decline in farm land price $\mathrm{x}$ agriculture } & $0.551 * * *$ & \\
\hline & $(0.209)$ & \\
\hline \multirow[t]{2}{*}{ Work in government } & & -0.0889 \\
\hline & & $(0.0701)$ \\
\hline Decline in farm land price $\mathrm{x}$ government & & -0.106 \\
\hline
\end{tabular}




\begin{tabular}{lcc}
\hline & $(1)$ & $(2)$ \\
& Main Model & Placebo Model \\
\hline & $\mathrm{X}$ & $(0.122)$ \\
Year dummies & $\mathrm{X}$ & $\mathrm{X}$ \\
PSU fixed effects & 5.391 & 5.954 \\
Constant & $(5.274)$ & 23180 \\
& 23180 & 214.7 \\
Observations & 216.3 & 0 \\
F-statistic & 0 & 0.200 \\
P-value & 0.200 & -0.014 \\
R-squared & $0.625 * * *$ & $(0.122)$ \\
Total effect of decline in farm prices & $(0.214)$ & \\
& $0.317 * *$ & $-0.195^{*}$ \\
Total effect of working in agriculture & $(0.138)$ & $(0.101)$ \\
Total effect of working in government & & 301 \\
Number of PSUs & 301 & \\
$* * * p<0.01, * * p<0.05, * p<0.1$ & & \\
Robust standard errors in parentheses, clustered by PSU. No high school diploma is the reference group \\
for degree. Protestant is the reference group for religion. White is the reference group for race. 1974 is the \\
reference year for the year dummies.
\end{tabular}

We see that the coefficient on the interaction effect between decline in farm prices and agriculture, $\alpha_{4}$ in Equation (1), is positive and significant, implying that those who work in agriculture in areas affected by the crisis increase their religious attendance about $1 / 5^{\text {th }}$ of a standard deviation, or $14 \%$ of the mean. From the placebo model we see that there is no significant effect of the decline in farm prices on the attendance of those who work in government. The social insurance model of religion seems to find support in this particular case as well. Those who work in government appear to be less religious from the outset, since the total effect of working in government is negative, significant, and $5 \%$ below the mean. However, almost all other industries in an affected area are likely to have suffered an adverse impact of the farm crisis, making government employees the only suitable placebo group. 
The next important question is: how long-lasting was this effect? I run the same regressions above but use a lagged decline in real farm prices as the treatment. This dummy variable takes on a value of 1 if there was a decline in real farm prices in the previous agricultural census. For example, if the real price in PSU $j$ is lower in the 1982 census than in the 1978 census, Lagged Decline $j$ t takes on a value of 1 for PSU $j$ for the years 1982 through 1986.

Table 4 reports the results of this regression for the relevant treatment and placebo variables.

Table 4: Results from Difference-in Difference Model. Dependent variable is religious attendance frequency, OLS with PSU and year fixed effects

\begin{tabular}{lcc}
\hline & $(1)$ & $(2)$ \\
& Main Model & Placebo Model \\
\hline Lagged decline in real price of farm land & $-0.0895^{*}$ & -0.0814 \\
& $(0.0520)$ & $(0.0523)$ \\
Work in agriculture & 0.0426 & \\
Lagged decline in farm land price x agriculture & $(0.156)$ & \\
& -0.00321 & -0.0709 \\
Work in government & $(0.214)$ & $(0.0783)$ \\
& & -0.120 \\
Lagged decline in farm land price x government & & $(0.121)$ \\
& & $\mathrm{X}$ \\
All other covariates from Table 4 & $\mathrm{X}$ & $\mathrm{X}$ \\
Year dummies & $\mathrm{X}$ & 7.581 \\
PSU fixed effects & $\mathrm{X}$ & $(5.427)$ \\
Constant & 7.465 & 22699 \\
& $(5.427)$ & 212.5 \\
Observations & 22699 & 0 \\
F-statistic & 212.4 & 0.200 \\
P-value & 0 & -0.201 \\
R-squared & 0.199 & $(0.126)$ \\
Total effect of lagged decline in farm prices & -0.093 & \\
Total effect of working in agriculture & $(0.218)$ & -0.191 \\
Total effect of working in government & 0.039 & $(0.094)$ \\
Number of PSUs & $(0.161)$ & 292 \\
\hline *** $\mathrm{p}<0.01, * * \mathrm{p}<0.05, * \mathrm{p}<0.1$ & & \\
Robust standard errors in parentheses, clustered by PSU. No high & school diploma is the reference group
\end{tabular}


for degree. Protestant is the reference group for religion. White is the reference group for race. 1974 is the reference year for the year dummies.

Table 4 shows that the effect appears to have dissipated fairly quickly. There is a strong contemporaneous effect of declining farm prices on religious attendance for the affected group, but no effect past the initial years.

Harl (1990) and Murdock and Leistritz (1988) describe how younger farmers were among the worst affected by the farm crisis. This may create a concern that if the average age of those remaining in agriculture were to rise as a result of the crisis, then non-random sample selection would lead to increased religious attendance. However, in the GSS data there is no significant difference in the average ages of farmers in the 1970s (53.6 years), 1980s (51.9 years), and 1990s $(50.25 \text { years })^{3}$

Another relevant question is whether this impact of declining farm prices occurred at all levels of religious attendance or not. Table 5 shows the results of a linear probability model regression on each level of attendance. We see that there is a significant increase in the probability of attending once a month, weekly, and more than once a week, and these increases are approximately $65 \%, 32 \%$, and $41 \%$ of the mean respectively. There is also a decline in the probability of attending less than once a year of about $51 \%$ of the mean.

\footnotetext{
${ }^{3}$ The t-test p-value comparing the ages of those working in agriculture in the 1970 s to the 1980 s is 0.29 and the pvalue comparing the $1980 \mathrm{~s}$ to the $1990 \mathrm{~s}$ is 0.27 . There is a significant difference between the $1970 \mathrm{~s}$ and the $1990 \mathrm{~s}(\mathrm{t}-$ test $\mathrm{p}$-value $=0.037$ ) but the average agricultural worker in the sample is, in fact, younger.
} 


\subsection{Robustness checks}

As an additional robustness check, I use county-level data on religious adherence rates from the Churches and Church Membership in the United States dataset compiled by the Association of Religion Data Archives (ARDA) for 1971, 1980, and 1990, and examine the effects of a decline in real farm prices on adherence rates per 100 residents, which are calculated as the total number of adherents in a county in a given year times 100, divided by the county population. The decline in farm land prices is calculated for each of the three years using the difference between the subsequent agricultural census year and the previous one - for example, if farm land prices declined between 1978 and 1982, the "Decline in farm land values" variable takes a value of 1 for 1980 .

I also classify denominations as Mainline or Evangelical using the taxonomy described by Steensland et. al. (2000), and examine adherence rates separately for them and Catholic churches. As they describe, among many other differences, Mainline denominations (the Episcopal Church, the United Methodist Church, the Evangelical Lutheran church, and others) have typically emphasized an accommodating stance towards modernity and a proactive view on issues of social and economic justice. Evangelical denominations (Southern Baptists, SeventhDay Adventists, Pentecostals, and others), on the other hand, have tended to emphasize separation from the broader culture relative to Mainline denominations, adherence to religious doctrines, and individual conversion and missionary activity. Ex ante, one might anticipate that Mainline denominations and the Catholic Church's emphasis on social and economic justice might make them more appealing during a financial crisis. 


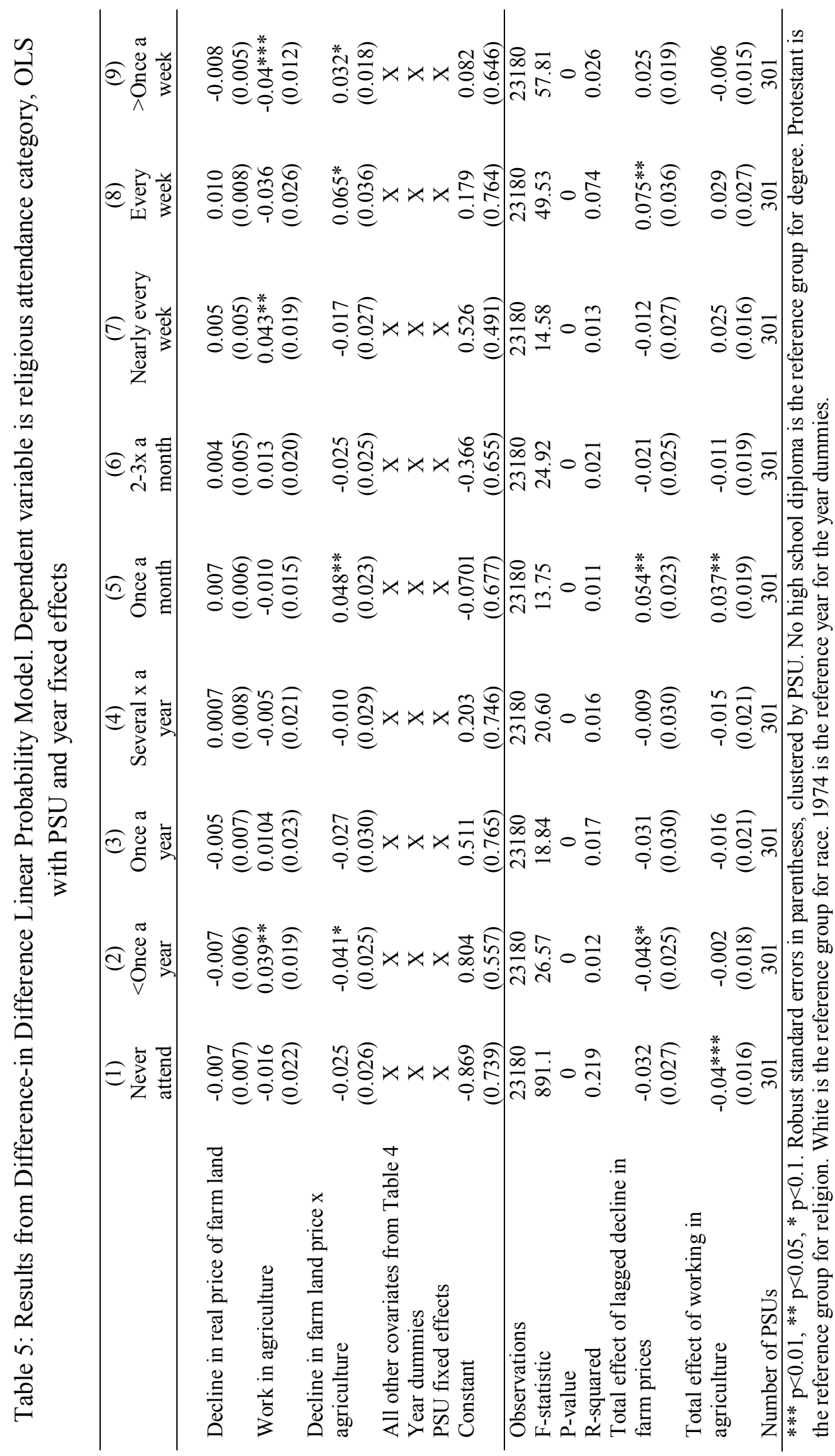


Alternatively, the closeness of an Evangelical church might better position it to provide public goods and a sense of community. Results are reported in Table 6.

Table 6: County-level adherence rates per 100 residents, OLS with county fixed effects

\begin{tabular}{lcccc}
\hline & $(1)$ & $(2)$ & $(3)$ & $(4)$ \\
& Overall & Mainline & Evangelical & Catholic \\
\hline \% Black & & & & \\
& 1.829 & $-23.18^{* * *}$ & $10.39^{* * *}$ & $-6.923^{* * *}$ \\
\% Other race & $(7.503)$ & $(3.546)$ & $(3.583)$ & $(2.324)$ \\
County population in millions & -1.557 & $5.401^{* * *}$ & -0.268 & 3.363 \\
& $(2.921)$ & $(0.550)$ & $(1.000)$ & $(2.719)$ \\
Ln(real per capita income) & $-8.863^{*}$ & 0.781 & $-7.546^{* * *}$ & -1.384 \\
& $(5.306)$ & $(0.747)$ & $(2.064)$ & $(2.474)$ \\
1980 & $8.093^{* * *}$ & $5.477^{* * *}$ & $-1.322^{*}$ & -0.0791 \\
& $(1.716)$ & $(0.819)$ & $(0.754)$ & $(0.855)$ \\
1990 & -0.0830 & $-5.496^{* * *}$ & $-0.596^{* * *}$ & $-0.376^{*}$ \\
& $(0.465)$ & $(0.257)$ & $(0.197)$ & $(0.211)$ \\
Farm revenue/Total county income & $3.313^{* * *}$ & $-7.331^{* * *}$ & $1.223^{* * *}$ & 0.190 \\
& $(0.723)$ & $(0.359)$ & $(0.334)$ & $(0.362)$ \\
Farm employment/Total county employment & $5.528^{* * *}$ & 1.654 & 0.315 & 0.684 \\
& $(1.758)$ & $(1.503)$ & $(0.436)$ & $(0.581)$ \\
Decline in real price of farm land & $-12.58^{* *}$ & $12.27^{* * *}$ & -0.190 & $6.481^{* *}$ \\
Constant & $(5.769)$ & $(3.602)$ & $(2.935)$ & $(2.682)$ \\
& $0.807^{* * *}$ & $-0.446^{* * *}$ & $0.295^{* *}$ & $0.369^{* *}$ \\
& $(0.289)$ & $(0.133)$ & $(0.119)$ & $(0.173)$ \\
Observations & -25.05 & $-37.19^{* * *}$ & $31.66^{* * *}$ & 13.23 \\
R-squared & $(16.92)$ & $(8.183)$ & $(7.395)$ & $(8.405)$ \\
F statistic & & & & \\
P-value on F statistic & 9,030 & 9,032 & 9,032 & 8,816 \\
& 0.128 & 0.281 & 0.044 & 0.009 \\
& 77.44 & 238.0 & 50.68 & 3.023 \\
& 0 & 0 & 0 & 0.0013 \\
& 3,026 & 3,027 & 3,027 & 3,026 \\
& & & &
\end{tabular}

Robust standard errors in parentheses, clustered by county. 1971 is the reference group for year.

$* * * \mathrm{p}<0.01, * * \mathrm{p}<0.05, * \mathrm{p}<0.1$

Column 1 looks at overall adherence rates, Column 2 at those for Mainline denominations, Column 3 is restricted to Evangelical denominations, while column 4 looks at 
adherence rates for Catholics. These results need to be interpreted with caution - data is only available for those denominations which reported data to the ARDA, and not all were present in all three - 1971, 1980, and 1990 - datasets. Additionally, some rural counties (26 counties in 1971, 32 in 1980, and 72 in 1990) have adherence rates greater than 100, implying either that churches in these counties may be drawing adherents from surrounding areas, or that churches overstate their adherence rates, or a combination of the two.

Still, acknowledging these limitations and the issues they entail, we see that a decline in the real price of farm land increases adherence rates per 100 residents by 0.81 overall. The mean adherence rate per 100 is 55.8 and the standard deviation is 19.4 , so while the effect is not numerically large, it is still statistically significant and meaningful, at about $4 \%$ of a standard deviation. Declining farm prices led to a decrease in adherence rates for mainline denominations of about 0.5 per 100 residents. The mean adherence rate for mainline denominations is 12.8 , and the standard deviation is 9.59 , implying a decline of $4.65 \%$ of a standard deviation. Evangelical denominations saw an increase of about 0.3 per 100 residents. The mean adherence rate for evangelical denominations is 18.8 with a standard deviation of 16.25 , so this amounts to an increase of $1.8 \%$ of a standard deviation. Catholic adherence rates increased by 0.37 per 100 residents. With a mean of 13.19 and a standard deviation of 15.3 , this amounts to an increase of $2.4 \%$ of a standard deviation. Overall, while adherence rates increased with a decline in farm land prices, this increase appears to have favored denominations generally thought of as more conservative.

Looking at the individual denominations, I find that adherence rates increased significantly when farm land prices declined for churches belonging to the following 
denominations: Church of Christ, Nazarene, Episcopal, Lutheran Church: Missouri Synod, Southern Baptist Conference, United Church of Christ, and the United Methodist Church. Of these, the Episcopal, United Church of Christ, and United Methodist churches are classified as Mainline, while the rest are classified as Evangelical. It decreased with a decrease in farm land prices for the Church of God (Tennessee), the Church of Jesus Christ and Latter-Day Saints, Free Methodist, and Salvation Army. There was no significant change (or insufficient data to properly estimate) for the remaining 28 denominations for which data was available for all three years. Detailed results of these regressions are available by request.

Additional robustness checks using the strength of religious affiliation (reported in the Appendix) find similar results - declining farm land prices led to an overall increase in adherence rates.

\section{Conclusion}

The goal of this study is to examine the 1980s farm crisis in the US as an example of severe financial distress with far-reaching consequences for the social and economic environment. My hypothesis is that religion forms a mechanism for the transmission and spread of changed attitudes, and that changes in religiosity occur in response to financial distress, as more strict denominations are better able to provide public goods and services to their members. Micro-level GSS data supports the hypothesis, as those who worked in agriculture in distressed areas tended to increase their religious attendance as farm prices fell, while those who worked in government did not. However, the mutual aid provided by the organizations may or may not have been financial - it may well have been the spiritual and emotional support that a religious 
community can provide. It also appears that this increase in religiosity was only temporary. Future research will incorporate data from the period after 2000, to be able to capture the impacts of the commodity price boom of the mid-2000s, which once again has led to increasing real farm land prices, and its impacts on rural religiosity, though these will need to be disentangled from the overall increase in real estate prices over the same period.

More interesting is the relationship this increase in religiosity may have had on crime, drug use, divorce rates, and other measures of welfare. This also remains a subject for future research.

\section{References}

Berman, Eli. 2009. Radical, Religious, and Violent: The New Economics of Terrorism. MIT Press.

Calomiris, Charles W. , R. Glenn Hubbard, James H. Stock and Benjamin M. Friedman. 1986.

“The Farm Debt Crisis and Public Policy.” Brookings Papers on Economic Activity, Vol. 1986, No. 2, pp. 441-485

Chen, Daniel L. 2010. “Club Goods and Group Identity: Evidence from Islamic Resurgence During the Indonesian Financial Crisis." Journal of Political Economy 118, no. 2: 300-354.

Davis-Brown, Karen, and Sonya Salamon. 1987. "Farm Families in Crisis: An Application of Stress Theory to Farm Family Research." Family Relations 36, no. 4: 368-373. 
Geller, Jack M., Gordon Bultena, and Paul Lasley. 1988. "Stress on the Farm: A Test of the lifeEvents Perspective Among Iowa Farm Operators*." The Journal of Rural Health 4, no. 2: 43-57.

Gruber, Jonathan \& Daniel M. Hungerman, 2008. "The Church versus the Mall: What Happens When Religion Faces Increased Secular Competition?," The Quarterly Journal of Economics, MIT Press, vol. 123(2): 831-862.

Harl, Neil E. 1990. The farm debt crisis of the 1980s. Iowa State University Press.

Hoyt, D.R., D. O’Donnell, and K.Y. Mack. 1995. “Psychological Distress and Size of Place: The Epidemiology of Rural Economic Stress." Rural Sociology 60, no. 4: 707-720.

Iannaccone, Laurence R.1992. "Sacrifice and Stigma: Reducing Free-riding in Cults, Communes, and Other Collectives.” Journal of Political Economy 100, no. 2: 271-291.

Lorenz, F.O., G.H. Elder Jr., W.-N. Bao, K.A.S. Wickrama, and R.D. Conger. 2000. “After Farming: Emotional Health Trajectories of Farm, Nonfarm, and Displaced Farm Couples." Rural Sociology 65, no. 1: 50-71.

Meyer, Katherine, and Linda Lobao. 2003. "Economic Hardship, Religion and Mental Health During the Midwestern Farm Crisis.” Journal of Rural Studies 19, no. 2: 139-155.

Murdock, Steve H., and F. Larry Leistritz. 1988. The Farm financial crisis: socioeconomic dimensions and implications for producers and rural areas. Westview special studies in agricultural science and policy, Westview Press

Ortega, S.T., D.R. Johnson, P.G. Beeson, and B.J. Craft. 1994. "The Farm Crisis and Mental 
Health: a Longitudinal Study of the 1980s." Rural Sociology 59, no. 4: 598-619.

Rajan, Raghuram, and Rodney Ramcharan. 2012. "The Anatomy of a Credit Crisis: The Boom and Bust in Farm Land Prices in the United States in the 1920s," NBER Working Papers 18027. National Bureau of Economic Research, Inc.

Steensland, B., J.Z. Park, M.D. Regnerus, L.D. Robinson, W.B. Wilcox, and R.D. Woodberry. 2000. "The Measure of American Religion: Toward Improving the State of the Art." Social Forces 79, no. 1: 291-318.

Thompson, Elizabeth A., and Hamilton I. McCubbin. 1987. "Farm Families in Crisis: An Overview of Resources." Family Relations 36, no. 4: 461-467. 


\section{Appendix: Additional tables and robustness checks}

In addition to the model described in equation 1 , an additional series of regressions were run that interacted the effect of a decline in the price of farm land with the dependence of a PSU on agriculture as an industry, to check if the effect of a decline in farm prices is more or less intense in areas that rely more heavily on farming. The "farm intensity" variable is constructed using factor analysis of two variables: the ratio of farm employment to total employment in a PSU, and the ratio of farm revenue to total income in a PSU. If we use any one of these variables individually, the results do not change in any meaningful way, but the index improves efficiency. Factor loadings are described in Table A1:

Table A1: Factor Loadings for Farm Intensity

\begin{tabular}{lll}
\hline Variable & Factor & Uniqueness \\
\hline Farm revenue/income ratio & 0.8628 & 0.2556 \\
Farm employment/total employment ratio & 0.8628 & 0.2556 \\
\hline
\end{tabular}

These regression results are detailed in table A2 for the main model and the placebo model. They are not different in any substantial way from the results reported in the paper - the effect of a decline in farm prices does appear to be affected by how heavily the area depends on agriculture. I also used strength of religious affiliation as a dependent variable. While the coefficient on decline in farm prices $\mathrm{x}$ agriculture is not significant in column (3) of Table A2, it is positive and the p-value is 0.105 . The coefficient of 0.184 implies an increase of $8 \%$ of the mean. Results for prayer frequency (available on request) also have similar findings despite a 
smaller sample size - the GSS only collected data on prayer frequency from 1983 onwards.

Table A2: Results from Difference-in Difference Model, robustness checks. OLS with PSU and year fixed effects

\begin{tabular}{|c|c|c|c|c|}
\hline & $\begin{array}{c}\text { (1) } \\
\text { Attendance } \\
\text { Main Model }\end{array}$ & $\begin{array}{c}\text { (2) } \\
\text { Attendance } \\
\text { Placebo Model }\end{array}$ & $\begin{array}{c}\text { (3) } \\
\text { Affiliation } \\
\text { strength } \\
\text { Main Model } \\
\end{array}$ & $\begin{array}{c}\text { (4) } \\
\text { Affiliation } \\
\text { strength } \\
\text { Placebo Model }\end{array}$ \\
\hline Age & $\begin{array}{c}0.0206 * * * \\
(0.00175)\end{array}$ & $\begin{array}{c}0.0207 * * * \\
(0.00175)\end{array}$ & $\begin{array}{c}0.0110 * * * \\
(0.000874)\end{array}$ & $\begin{array}{l}0.0111 * * * \\
(0.000875)\end{array}$ \\
\hline Mother attended weekly & $\begin{array}{c}0.526^{* * * *} \\
(0.0720)\end{array}$ & $\begin{array}{l}0.526^{* * * *} \\
(0.0722)\end{array}$ & $\begin{array}{l}0.213 * * * \\
(0.0469)\end{array}$ & $\begin{array}{l}0.213 * * * \\
(0.0470)\end{array}$ \\
\hline Father attended weekly & $\begin{array}{c}0.503 * * * \\
(0.0790)\end{array}$ & $\begin{array}{c}0.503 * * * \\
(0.0792)\end{array}$ & $\begin{array}{l}0.288 * * * \\
(0.0503)\end{array}$ & $\begin{array}{c}0.288 * * * \\
(0.0503)\end{array}$ \\
\hline Ever switched religions & $\begin{array}{l}0.324 * * * \\
(0.0518)\end{array}$ & $\begin{array}{l}0.325 * * * \\
(0.0517)\end{array}$ & $\begin{array}{l}0.0525 * \\
(0.0316)\end{array}$ & $\begin{array}{l}0.0528^{*} \\
(0.0316)\end{array}$ \\
\hline Catholic & $\begin{array}{l}0.380 * * * \\
(0.0533)\end{array}$ & $\begin{array}{l}0.381 * * * \\
(0.0531)\end{array}$ & $\begin{array}{c}-0.00834 \\
(0.0281)\end{array}$ & $\begin{array}{r}-0.00802 \\
(0.0281)\end{array}$ \\
\hline Jewish & $\begin{array}{c}-1.169 * * * \\
(0.106)\end{array}$ & $\begin{array}{c}-1.170^{* * *} \\
(0.106)\end{array}$ & $\begin{array}{c}0.0909 \\
(0.0720)\end{array}$ & $\begin{array}{c}0.0898 \\
(0.0719)\end{array}$ \\
\hline No religion & $\begin{array}{c}-2.932 * * * \\
(0.0557)\end{array}$ & $\begin{array}{c}-2.933 * * * \\
(0.0557)\end{array}$ & $\begin{array}{c}-2.220 * * * \\
(0.0317)\end{array}$ & $\begin{array}{c}-2.221 * * * \\
(0.0317)\end{array}$ \\
\hline Other religion & $\begin{array}{c}-0.625^{* * *} \\
(0.130)\end{array}$ & $\begin{array}{c}-0.628 * * * \\
(0.130)\end{array}$ & $\begin{array}{l}0.452 * * * \\
(0.0650)\end{array}$ & $\begin{array}{c}0.450 * * * \\
(0.0652)\end{array}$ \\
\hline Buddhism & $\begin{array}{c}-1.144 * * \\
(0.501)\end{array}$ & $\begin{array}{c}-1.134 * * \\
(0.499)\end{array}$ & $\begin{array}{l}-0.0659 \\
(0.285)\end{array}$ & $\begin{array}{r}-0.0615 \\
(0.285)\end{array}$ \\
\hline Hinduism & $\begin{array}{l}-0.946 \\
(0.776)\end{array}$ & $\begin{array}{l}-0.949 \\
(0.776)\end{array}$ & $\begin{array}{l}-0.147 \\
(0.652)\end{array}$ & $\begin{array}{l}-0.150 \\
(0.652)\end{array}$ \\
\hline Other Eastern religion & $\begin{array}{c}1.908 * * * \\
(0.282)\end{array}$ & $\begin{array}{c}1.899 * * * \\
(0.287)\end{array}$ & $\begin{array}{c}1.413 * * * \\
(0.105)\end{array}$ & $\begin{array}{c}1.409 * * * \\
(0.102)\end{array}$ \\
\hline Islam & $\begin{array}{c}0.577 \\
(0.885)\end{array}$ & $\begin{array}{c}0.574 \\
(0.886)\end{array}$ & $\begin{array}{c}0.628 * * \\
(0.288)\end{array}$ & $\begin{array}{c}0.627 * * \\
(0.286)\end{array}$ \\
\hline Orthodox Christian & $\begin{array}{l}0.0262 \\
(0.315)\end{array}$ & $\begin{array}{l}0.0160 \\
(0.314)\end{array}$ & $\begin{array}{c}0.137 \\
(0.285)\end{array}$ & $\begin{array}{c}0.132 \\
(0.285)\end{array}$ \\
\hline Christian & $\begin{array}{c}0.752 * * \\
(0.329)\end{array}$ & $\begin{array}{c}0.743 * * \\
(0.330)\end{array}$ & $\begin{array}{c}0.799 * * * \\
(0.161)\end{array}$ & $\begin{array}{c}0.797 * * * \\
(0.160)\end{array}$ \\
\hline Native American & $\begin{array}{l}-0.825 \\
(0.774)\end{array}$ & $\begin{array}{l}-0.831 \\
(0.773)\end{array}$ & $\begin{array}{c}1.346 * * * \\
(0.236)\end{array}$ & $\begin{array}{c}1.343 * * * \\
(0.236)\end{array}$ \\
\hline Inter/Nondenominational & $\begin{array}{l}0.0839 \\
(0.404)\end{array}$ & $\begin{array}{l}0.0786 \\
(0.404)\end{array}$ & $\begin{array}{c}0.791 * * * \\
(0.244)\end{array}$ & $\begin{array}{c}0.787 * * * \\
(0.244)\end{array}$ \\
\hline Female & $\begin{array}{l}0.419 * * * \\
(0.0324)\end{array}$ & $\begin{array}{c}0.414 * * * \\
(0.0322)\end{array}$ & $\begin{array}{c}0.202 * * * \\
(0.0183)\end{array}$ & $\begin{array}{l}0.199 * * * \\
(0.0182)\end{array}$ \\
\hline Number of children & $\begin{array}{c}0.0690 * * * \\
(0.0122)\end{array}$ & $\begin{array}{c}0.0687 * * * \\
(0.0121)\end{array}$ & $\begin{array}{c}0.0168 * * * \\
(0.00635)\end{array}$ & $\begin{array}{c}0.0166 * * * \\
(0.00635)\end{array}$ \\
\hline Married & $\begin{array}{c}0.388 * * * \\
(0.0354)\end{array}$ & $\begin{array}{c}0.389 * * * \\
(0.0354)\end{array}$ & $\begin{array}{c}0.125 * * * \\
(0.0194)\end{array}$ & $\begin{array}{c}0.126^{* * *} \\
(0.0193)\end{array}$ \\
\hline Employed & $\begin{array}{l}0.109 * * \\
(0.0465)\end{array}$ & $\begin{array}{l}0.108 * * \\
(0.0465)\end{array}$ & $\begin{array}{c}0.0248 \\
(0.0272)\end{array}$ & $\begin{array}{c}0.0249 \\
(0.0271)\end{array}$ \\
\hline Ln(personal income) & $-0.138 * * *$ & $-0.136 * * *$ & $-0.0627 * * *$ & $-0.0618 * * *$ \\
\hline
\end{tabular}




\begin{tabular}{|c|c|c|c|c|}
\hline & $\begin{array}{c}\text { (1) } \\
\text { Attendance } \\
\text { Main Model }\end{array}$ & $\begin{array}{c}(2) \\
\text { Attendance } \\
\text { Placebo Model }\end{array}$ & $\begin{array}{c}\text { (3) } \\
\text { Affiliation } \\
\text { strength } \\
\text { Main Model }\end{array}$ & $\begin{array}{c}\text { (4) } \\
\text { Affiliation } \\
\text { strength } \\
\text { Placebo Model }\end{array}$ \\
\hline & $(0.0175)$ & $(0.0175)$ & $(0.00998)$ & $(0.0100)$ \\
\hline Black & $\begin{array}{c}0.802 * * * \\
(0.0580)\end{array}$ & $\begin{array}{c}0.808^{* * *} * \\
(0.0581)\end{array}$ & $\begin{array}{c}0.321 * * * \\
(0.0299)\end{array}$ & $\begin{array}{c}0.324 * * * \\
(0.0297)\end{array}$ \\
\hline Other race & $\begin{array}{c}0.477 * * * \\
(0.0799)\end{array}$ & $\begin{array}{c}0.478 * * * \\
(0.0798)\end{array}$ & $\begin{array}{c}0.0536 \\
(0.0504)\end{array}$ & $\begin{array}{c}0.0543 \\
(0.0503)\end{array}$ \\
\hline High school & $\begin{array}{c}0.543 * * * \\
(0.0509)\end{array}$ & $\begin{array}{c}0.549 * * * \\
(0.0506)\end{array}$ & $\begin{array}{c}0.109 * * * \\
(0.0265)\end{array}$ & $\begin{array}{c}0.112 * * * \\
(0.0264)\end{array}$ \\
\hline Junior college & $\begin{array}{c}0.902 * * * \\
(0.0787)\end{array}$ & $\begin{array}{c}0.910 * * * \\
(0.0781)\end{array}$ & $\begin{array}{c}0.204 * * * \\
(0.0477)\end{array}$ & $\begin{array}{c}0.209^{* * *} \\
(0.0477)\end{array}$ \\
\hline Bachelor's & $\begin{array}{c}1.222 * * * \\
(0.0666)\end{array}$ & $\begin{array}{c}1.228 * * * \\
(0.0661)\end{array}$ & $\begin{array}{c}0.338 * * * \\
(0.0354)\end{array}$ & $\begin{array}{c}0.342 * * * \\
(0.0352)\end{array}$ \\
\hline Graduate degree & $\begin{array}{c}1.285^{* * *} \\
(0.0822)\end{array}$ & $\begin{array}{c}1.288 * * * \\
(0.0818)\end{array}$ & $\begin{array}{c}0.370 * * * \\
(0.0463)\end{array}$ & $\begin{array}{c}0.372 * * * \\
(0.0462)\end{array}$ \\
\hline PSU population in millions & $\begin{array}{c}0.190 \\
(0.151)\end{array}$ & $\begin{array}{c}0.190 \\
(0.151)\end{array}$ & $\begin{array}{c}0.0752 \\
(0.0979)\end{array}$ & $\begin{array}{c}0.0776 \\
(0.0980)\end{array}$ \\
\hline Ln(real per capita PSU income) & $\begin{array}{l}-0.355 \\
(0.530)\end{array}$ & $\begin{array}{l}-0.374 \\
(0.533)\end{array}$ & $\begin{array}{c}0.111 \\
(0.307)\end{array}$ & $\begin{array}{l}0.0894 \\
(0.307)\end{array}$ \\
\hline Percent change in real per capita PSU income & $\begin{array}{c}1.058 \\
(0.889)\end{array}$ & $\begin{array}{c}1.023 \\
(0.890)\end{array}$ & $\begin{array}{c}0.260 \\
(0.530)\end{array}$ & $\begin{array}{c}0.239 \\
(0.531)\end{array}$ \\
\hline Farm intensity & $\begin{array}{l}-0.270 \\
(0.216)\end{array}$ & $\begin{array}{l}-0.293 \\
(0.214)\end{array}$ & & \\
\hline Farm revenue/Total PSU income & & & $\begin{array}{c}-0.0263 \\
(0.542)\end{array}$ & $\begin{array}{c}0.00130 \\
(0.549)\end{array}$ \\
\hline Farm employment/Total PSU employment & & & $\begin{array}{l}-1.815 \\
(1.695)\end{array}$ & $\begin{array}{l}-1.946 \\
(1.689)\end{array}$ \\
\hline Decline in real price of farm land & $\begin{array}{c}0.0668 \\
(0.0506)\end{array}$ & $\begin{array}{l}0.0879 * \\
(0.0518)\end{array}$ & $\begin{array}{c}0.0278 \\
(0.0306)\end{array}$ & $\begin{array}{c}0.0322 \\
(0.0312)\end{array}$ \\
\hline Work in agriculture & $\begin{array}{l}-0.256 \\
(0.187)\end{array}$ & & $\begin{array}{l}-0.0618 \\
(0.0795)\end{array}$ & \\
\hline Decline in farm land price $\mathrm{x}$ agriculture & $\begin{array}{c}0.508^{* *} \\
(0.250)\end{array}$ & & $\begin{array}{l}0.184^{\wedge} \\
(0.113)\end{array}$ & \\
\hline Decline in farm land price $\mathrm{x}$ farm intensity & $\begin{array}{c}-0.0704 \\
(0.0464)\end{array}$ & $\begin{array}{c}-0.0335 \\
(0.0439)\end{array}$ & & \\
\hline Agriculture $\mathrm{x}$ farm intensity & $\begin{array}{l}0.00426 \\
(0.0604)\end{array}$ & & & \\
\hline $\begin{array}{l}\text { Decline in farm land price } x \text { agriculture } x \\
\text { farm intensity }\end{array}$ & $\begin{array}{l}0.0676 \\
(0.0946)\end{array}$ & & & \\
\hline Work in government & & $\begin{array}{l}-0.0788 \\
(0.0688)\end{array}$ & & $\begin{array}{l}-0.0682 \\
(0.0431)\end{array}$ \\
\hline Decline in farm land price $\mathrm{x}$ government & & $\begin{array}{l}-0.112 \\
(0.121)\end{array}$ & & $\begin{array}{l}-0.0211 \\
(0.0622)\end{array}$ \\
\hline Government $\mathrm{x}$ farm intensity & & $\begin{array}{c}0.0932 \\
(0.0648)\end{array}$ & & \\
\hline $\begin{array}{l}\text { Decline in farm land price } \mathrm{x} \text { government } \mathrm{x} \\
\text { farm intensity }\end{array}$ & & $\begin{array}{l}-0.115 \\
(0.109)\end{array}$ & & \\
\hline
\end{tabular}




\begin{tabular}{|c|c|c|c|c|}
\hline & $\begin{array}{c}\text { (1) } \\
\text { Attendance } \\
\text { Main Model }\end{array}$ & $\begin{array}{c}\text { (2) } \\
\text { Attendance } \\
\text { Placebo Model }\end{array}$ & $\begin{array}{c}\text { (3) } \\
\text { Affiliation } \\
\text { strength } \\
\text { Main Model } \\
\end{array}$ & $\begin{array}{c}\text { (4) } \\
\text { Affiliation } \\
\text { strength } \\
\text { Placebo Model }\end{array}$ \\
\hline Year dummies & $\mathrm{X}$ & $\mathrm{X}$ & $\mathrm{X}$ & $\mathrm{X}$ \\
\hline PSU fixed effects & $\mathrm{X}$ & $\mathrm{X}$ & $\mathrm{X}$ & $\mathrm{X}$ \\
\hline Constant & $\begin{array}{c}6.587 \\
(5.283) \\
\end{array}$ & $\begin{array}{c}6.758 \\
(5.316) \\
\end{array}$ & $\begin{array}{c}0.973 \\
(3.097)\end{array}$ & $\begin{array}{c}1.185 \\
(3.103)\end{array}$ \\
\hline Observations & 23180 & 23180 & 22538 & 22538 \\
\hline F-statistic & 208.6 & 208.4 & 603.0 & 610.2 \\
\hline P-value & 0 & 0 & 0 & 0 \\
\hline R-squared & 0.200 & 0.200 & 0.255 & 0.255 \\
\hline Total effect of decline in farm prices & $\begin{array}{c}0.572 * * * \\
(0.215)\end{array}$ & $\begin{array}{l}-0.173 \\
(0.151)\end{array}$ & $\begin{array}{l}0.212^{*} \\
(0.116)\end{array}$ & $\begin{array}{c}0.011 \\
(0.063)\end{array}$ \\
\hline Total effect of working in agriculture & $\begin{array}{c}0.324^{* *} \\
(0.141)\end{array}$ & & $\begin{array}{c}0.122 \\
(0.079)\end{array}$ & \\
\hline Total effect of working in government & & $\begin{array}{l}-0.213 \\
(0.141)\end{array}$ & & $\begin{array}{c}-0.089 * * \\
(0.046)\end{array}$ \\
\hline Number of PSUs & 301 & 301 & 301 & 301 \\
\hline
\end{tabular}

$* * * \mathrm{p}<0.01,{ }^{* *} \mathrm{p}<0.05,{ }^{*} 0.105<\mathrm{p}<0.1, \wedge \mathrm{p}=0.105$.

Robust standard errors in parentheses. Standard errors are clustered by PSU in the OLS model and PSU $\mathrm{x}$ year in the ordered logit. Ordered logit odds ratios are reported. No high school diploma is the reference group for degree. Protestant is the reference group for religion. White is the reference group for race. 